\title{
Validation of nursing diagnosis for nursing consultation on home visit to adults
}

\author{
Validação de diagnósticos de enfermagem para consulta de enfermagem na visita domiciliar ao adulto \\ Validez de diagnóstico de enfermería para consulta de enfermería en la visita domiciliaria al adulto
}

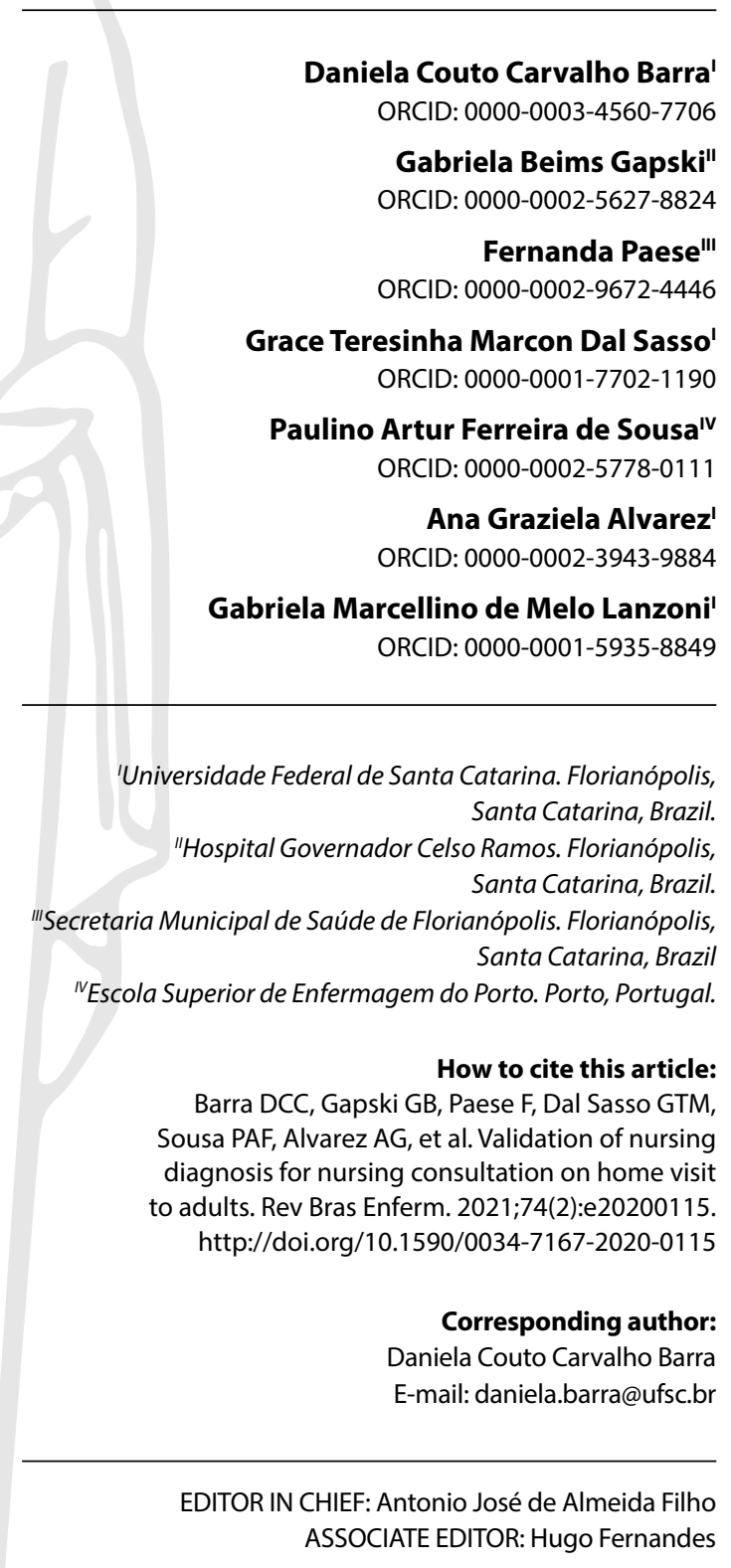

Submission: $04-19-2020$

Approval: 11-11-2020

\begin{abstract}
Objectives: to identify and confirm the priority nursing diagnosis of International Classification for Nursing Practice for home nursing consultation to adults in Primary Health Care. Methods: qualitative study, of methodological and validation type. The 5-point Likert scale was used, with a minimum Content Validity Index of $80 \%$ consensus among judges., considering the answers "priority" or "very priority" for the list of nursing diagnoses presented. 23 expert judges participated in this survey. Results: a hundred and eleven nursing diagnoses of prepared statements lists have been grouped by human systems and sociodemographic characteristics. were grouped by human systems and sociodemographic characteristics. Eighty-three of them (74.77\%) had a Content Validity Index equal or higher to 0.8 ; and 27 $(32.5 \%)$ had an index of $1.0(100 \%)$ among judges. Conclusions: nursing diagnosis validated can be used to assist clients in home nursing consultations in Primary Health Care.

Descriptors: Validation Study; Nursing Diagnosis; Standardized Nursing Terminology; House Calls; Homebound Persons.
\end{abstract}

\section{RESUMO}

Objetivos: identificar e validar os diagnósticos de enfermagem prioritários da Classificação Internacional para a Prática de Enfermagem " para a consulta de enfermagem domiciliar do adulto na Atenção Primária à Saúde. Métodos: estudo quantitativo, do tipo metodológico e de validação. Utilizou-se a escala Likert de 5 pontos, com o Índice de Validade de Conteúdo mínimo de $80 \%$ de consenso entre os juízes, considerando as respostas "prioritário" ou "muito prioritário" para a lista de diagnósticos de enfermagem apresentada. Participaram da pesquisa 23 juízes especialistas. Resultados: os 111 diagnósticos de enfermagem da lista de enunciados elaborada foram agrupados por sistemas humanos e características sociodemográficas. Destes, 83 (74,77\%) obtiveram Índice de Validade de Conteúdo maior ou igual a 0,8; e 27 (32,5\%) obtiveram índice 1,0 (100\%) entre juízes. Conclusões: os Diagnósticos de Enfermagem validados podem ser utilizados no atendimento aos clientes nas consultas de enfermagem domiciliares na Atenção Primária à Saúde.

Descritores: Estudos de Validação; Diagnóstico de Enfermagem; Terminologia Padronizada em Enfermagem; Visita Domiciliar; Pacientes Domiciliares.

\section{RESUMEN}

Objetivos: identificar e validar diagnósticos de enfermería prioritarios de la Clasificación Internacional para Práctica de Enfermería para consulta de enfermería domiciliaria del adulto en la Atención Primaria de Salud. Métodos: estudio cuantitativo, del tipo metodológico y de validez. Utilizó escala Likert de 5 puntos, con Índice de Validez de Contenido mínimo de $80 \%$ de consenso entre los jueces, considerando las respuestas "prioritario" o "muy prioritario" para la lista de diagnósticos de enfermería presentada. Participaron de la investigación 23 jueces especialistas. Resultados: los 111 diagnósticos de enfermería de la lista de enunciados elaborada, agrupados por sistemas humanos y características sociodemográficas. De estos, $83(74,77 \%)$ obtuvieron Índice de Validez de Contenido mayor o igual a 0,8; e 27 (32,5\%) obtuvieron índice 1,0 (100\%) entre jueces. Conclusiones: los Diagnósticos de Enfermería validados pueden ser utilizados en la atención a los clientes en las consultas de enfermería domiciliarias en la Atención Primaria de Salud.

Descriptores: Estudios de Validez; Diagnóstico de Enfermería; Terminología Estandarizada en Enfermería; Visita Domiciliaria; Pacientes Domiciliarios. 


\section{INTRODUCTION}

Nursing consultation is one of the nurses' actions. As a private activity, it offers autonomy to the professional, requiring technicalscientific knowledge to identify health-disease situations and perform qualified and safe care to the client ${ }^{(1-3)}$. It may be done in several clinical areas and contexts, including home ${ }^{(1-2)}$.

In the context of Home Care, a nursing home consultation is a valuable tool that allows the professional to carry out the consultation associating fundamentals to the condition/situation evaluation in which the clients and their families are. Also, it increases the professional-client bond, has the potential to expand and qualify the care process, and can offer service to clients with mobility issues to reach a health service unit ${ }^{(3-6)}$.

Home care encompasses the terms "home visit"and"home consultation."Home care aims to develop prevention and disease treatment actions, rehabilitation, palliative care, health promotion, ensuring continuity of care at home, and seeking to reduce hospital practices ${ }^{(2,7)}$.

Among the clinical conditions usually present in Home Care, we can find immobility and fragility syndromes, cognitive dysfunctions, sensory deficits, acute and/or chronic respiratory diseases, cardiovascular diseases, renal dysfunctions, wounds, and other skin tissue disorders, neurofunctional and nutritional rehabilitation, digestive changes, mental disorders, infectious and contagious diseases, and musculoskeletal diseases ${ }^{(8)}$.

Such conditions are often associated and make difficult the search for health and/or adherence to the treatment. Those factors may cause the progressive impairment of mobility, increase the possibility of falls or body injuries through domestic accidents, acute or chronic pain, fractures, fatigue, atrophies, infections, low immunity, difficulty in self-care, and also often lead to social isolation. However, it is noticed that clinical conditions may be avoided through correct and safe healthcare, aiming to promote health and prevent diseases ${ }^{(8)}$.

To integrate all information present in home nursing consultation, it is essential to adopt standardized terminology to facilitate communication among the nursing practitioner and the other multidisciplinary team members about the health practice. The International Classification for Nursing Practice (ICNP ${ }^{\circ}$ ) is a terminology that reaches such aim and establishes criteria, based on the International Organization for Standardization (ISO) 18.104, for the standardized formulation of Nursing Diagnoses and Interventions ${ }^{(9-13)}$.

It is considered that this study is justified: by the possibility the nurse has to perform the nursing consulting in home environment with the scientific method and based on the ICNP', a worldly used terminology; by the language standardization of nursing based on the ICNP' ${ }^{\circ}$, as a way to improve communication among peers, promote the analysis and comparison of results obtained, and make feasible the identification of their area of knowledge; and by the visibility of the nurses' work in the society by the improvement of quality of direct care and the results achieved with users, through an activity that is mandatory in the field of nursing.

\section{OBJECTIVES}

To identify and validate the priority nursing diagnoses of the International Classification for Nursing Practice for home nursing consultation to adults in Health Primary Care.

\section{METHODS}

\section{Ethical aspects}

This survey was approved by the Human Research Ethics Committee of the Federal University of Santa Catarina, according to Resolution No. 466/2012 of the National Health Council of the Ministry of Health of Brazil. All the participants of the study signed the Informed Consent Form.

It is worth to mention that this study refers to one of the adopted stages for the development of a mobile application prototype (app) for home nursing consultation in adult health. This prototype will provide data and information to nurses related to the client's detailed clinical evaluation; Nursing Diagnoses validated in this study; and Nursing Intervention.

\section{Design, place and period of study}

Quantitative, methodological ${ }^{(14-15)}$ and validation (analytical descriptive) study guided by the GREET ${ }^{(14)}$ tool, nationally carried out, in for Regions of Brazil (South, Southeast, Middle-West, and Northeast), between April and December 2019.

\section{Population and sample}

The population of the study was provided with 170 nurses that met the delimited inclusion and exclusion criteria; and was identified through a search on the Lattes Platform, according to the inclusion criteria established for the study. Nurses from the five Brazilian regions were selected, although in the cohabitation sample, no nurse from the northern region responded to the letter of invitation.

The criteria for the inclusion of expert judges were: be a nurse, of Brazilian nationality, and have a minimum score of 5 (five) points according to the characteristics adapted from Fehring ${ }^{(16)}$, considering the following score: thesis and/or dissertation on the theme ICNP ${ }^{\circ}$ and/or Primary Care -2 points; have published articles in National and/or International journals, focused on the topic ICNP ${ }^{\circ}$ and/or Primary Care and/or home nursing consultation - 2 points; experience in the validation of instruments and/ or content - 2 points; participation in research groups/projects that work with the topic ICNP ${ }^{\circ}$ and/or Primary Care and/or home nursing consultation - 1 point; specialization in family health and/ or Primary Health Care - 1 point; Minimum practice experience of 12 months in the Primary Care area and/or Home Care - 1 point.

Exclusion criteria were: nurses that did not reach the minimum score of 5 and did not answer the survey form within 30 days and after 3 attempts.

The invitation letter was sent by email to 170 professionals in three attempts each 15 days, and 28 answered the invitation. The sample had 23 participants since 5 were excluded for not answering the data collection instrument within the requested deadline.

\section{Study protocol}

The study of methodological type ${ }^{(14-15)}$ was adopted to identify Nursing Diagnoses for home nursing consultation in adult health in Primary Care. The methodological study was conducted for 5 structured stages that made possible the elaboration and selection 
of a list/term base of the Nursing Diagnostics of the ICNP', which composed the groups of each human system for further validation of the expert judges, namely: Stage 1 - a literature review with a theoretical deepening of the ISO Standard 18.104, ICNP', home nursing consultation and a Primary Health Care (PHC), through research carried out in scientific databases; Stage 2 - a selection of terms of the ICNP's axis-focus for the structure of the termbase related to $\mathrm{PHC}$ and home nursing consultation; Stage 3-elaboration of Nursing Diagnoses based on the termbases previously selected (ICNP's axis-focus and judging); and Stage 4-a grouping of Nursing Diagnostics according to the human systems and sociodemographic aspects of clients.

The study of validation type $\mathrm{e}^{(14,17)}$ was carried out in Stage 5 to validate the priority Nursing Diagnoses for home nursing consultation by expert judges.

Data collection was done through a form on the Google Forms platform, divided into two parts. The first addressed the sociodemographic characterization, area of expertise, and expert judges' knowledge about the research theme. The second part presented the groups of Nursing Diagnoses by human systems (neurologic, respiratory, cardiovascular, digestive and renal, reproductive, tegumental e musculoskeletal); and the sociodemographic aspects of the clients.

For evaluation of all Nursing Diagnoses by the expert judges, the 5-point Likert scale was used, in which, for each diagnosis, the participant should select one option, specified as 1) not applicable; 2) little priority; 3) low priority; 4) priority and; 5) high priority.

\section{Data Analysis}

Data obtained was organized in Microsoft Excel (version 2016) spreadsheets and analyzed quantitatively. The Content Validity Index (CVI) was used with a minimum consensus value of $80 \%{ }^{(17)}$ among expert judges, considering the answers "priority" or "very priority" to validate the diagnoses. However, it is worth to mention that "satisfactory CVI" was attributed to Nursing Diagnoses that obtained consensus among judges between $45 \%$ to $79 \%$.

For calculation of $\mathrm{CVI}$, the following formula was applied:

$C V I=($ Number of Answers as "Priority" and "Very Priority" $\times 100)$

Total Number of Answers

The relative frequency of agreement was obtained from the sum of answers that received the score 4 ("priority") and score 5 ("very priority"), to each Nursing Diagnosis, divided by the total number of participants that answered the survey.

\section{RESULTS}

\section{Sociodemographic characterization of expert judges}

Twenty-three nurses participated in the study, 91.4\% $(\mathrm{n}=$ 21 ) were of female gender, and $8.6 \%(n=2)$ of male gender. The predominant age group was 35 to 44 years, with $69.6 \%(n=16)$. Judge's graduation time ranged from 3 to 34 years, with an average time of 12 years.
Regarding the degree of the titles of the expert judges, 95.7\% ( $=22$ ) affirmed are specialists; $17.4 \%(n=4)$, have medical residency; 43.5\% ( $n=10)$, master's degree; $21.7 \%(n=5)$, doctorate; and $13 \%(n$ $=3)$, postdoctoral. One expert judge (4.3\%) responded to having an additional MBA. In this item, the 23 judges could have chosen more than one option, in a way that there were more than 23 answers.

Regarding the current location of the judges, the following results were obtained: $56.5 \%(n=13)$, in assistance; $21.7 \%(n=5)$ in teaching; $30.4 \%(n=7)$, in survey; $17.3 \%$, in management; and $4.3 \%$ ( =1) marked "others", referring to the university extension activity.

From 23 participating judges, 95.6\% $(n=22)$ affirmed that work or have already worked in Health Primary Care, ranging from 1 to 20 years of experience, with an average time of 6.5 years. Regarding the use of the ICNP' $60.8 \%(n=14)$ of judges said they used this classification in their professional practice, ranging from 1 to 15 years of use, with an average time of 5.9 years. Regarding the APS and/or Family Health Strategy (EST) knowledge, 47.8\% ( $n=$ 11) of judges declared have a "High" knowledge; $43.5 \%(n=10)$, "Intermediate" knowledge; and 8.7\% ( $n=2)$, "Little" knowledge.

\section{Validation of Priority Nursing Diagnoses for home consultation}

In Stage 4, 111 Nursing Diagnoses (ND) of the ICNP ${ }^{\circ}$ were elaborated (axis-focus and judging) for home nursing consultation in Primary Health Care, based on the literature and theoreticalscientific knowledge of the researcher. Of the $111 \mathrm{NDs}, 83$ (74.8\%) had Content Validity Index (CVI) $\geq 0.8$, and 28 (25.2\%) were not validated, though, they had CVI satisfactory (45\% to $79 \%$ ), according to the expert judges.

Table 1 presents validated and non-validated NDs by human systems, organized in neurologic, respiratory, cardiovascular, digestive and renal, tegumental, musculoskeletal and reproductive systems; and sociodemographic aspects of clients, which include elements related to the client, caregiver, and environment, directly dependent on sociodemographic conditions.

Table 1 - Number of Nursing Diagnoses of the ICNP ${ }^{\circ}$ validated and nonvalidated by the export judges, Florianópolis, Santa Catarina, Brazil, 2019

\begin{tabular}{lccccc}
\hline $\begin{array}{l}\text { Nursing Diagnoses } \\
\text { by human systems }\end{array}$ & $\begin{array}{c}\text { Elaborated } \\
\text { NDs } \\
\text { (n) }\end{array}$ & \multicolumn{2}{c}{$\begin{array}{c}\text { Validated } \\
\text { NDs }\end{array}$} & \multicolumn{3}{c}{$\begin{array}{c}\text { Non-validated } \\
\text { NDs }\end{array}$} \\
& 19 & 17 & 89.5 & 2 & 10.5 \\
& (n) & (n) \\
\hline Neurologic System & 11 & 7 & 63.6 & 4 & 36.4 \\
Respiratory System & 9 & 6 & 66.6 & 3 & 33.4 \\
Cardiovascular System & 15 & 10 & 66.6 & 5 & 33.4 \\
Digestive and Renal System & 18 & 16 & 88.9 & 2 & 11.1 \\
Tegumental System & 13 & 8 & 61.5 & 5 & 38.5 \\
Musculoskeletal System & 1 & 0 & 0 & 1 & 100 \\
Reproductive System & 25 & 19 & 76 & 6 & 24 \\
Sociodemographic Aspects & 111 & 83 & 74.8 & 28 & 25.2 \\
TOTAL & & & & &
\end{tabular}

Of 83 Nursing Diagnoses with CVI $\geq 0.8,27$ (32.5\%) had CVI of $1.0(100 \%)$ by the expert judges. From them, $3(11.1 \%)$ were of neurologic system; 2 (7.4\%), of respiratory system; 2 (7.4\%), of cardiovascular system; 8 (29.6\%), of tegumental system; 4 (14.8\%), of musculoskeletal system; and 8 (29.6\%) referred to sociodemographic aspects of clients/users. 
Table 2 presents 83 (74.8\%) Nursing Diagnoses validated by the experts. NDs are presented according to the human systems previously carried out in Stage 4 of the study.

Table 2 - 2017 ICNP's Nursing Diagnoses Statements validated and the Content Validity Index, Florianópolis, Santa Catarina, Brazil, 2019

\begin{tabular}{ll}
\hline Validated Nursing Diagnoses of the ICNP \\
\hline Neurologic System - Total of 17 validated NDs \\
1 & Pain \\
2 & Impaired Memory \\
3 & Sign of Discomfort \\
4 & Ability to Participate in Impaired Care Planning \\
5 & Ability to Participate in Effective Care Planning \\
6 & Impaired Neurologic Condition \\
7 & Presence of Depresses Humor \\
8 & Postural Vertigo (Dizziness) \\
9 & Anxiety \\
10 & Ability to Communicate Impaired Needs \\
11 & Presence of Anguish \\
12 & Ability to Communicate Effective Needs \\
13 & Ability to Perform Effective Self-Care \\
14 & Agitation \\
15 & Cry Present \\
16 & Impaired Psychological Condition \\
17 & Absent Pain \\
\hline & Respiratory System - Total of 7 NDs validated \\
1 & Impaired Respiratory Condition \\
2 & Risk of Respiratory Infection \\
3 & Cough \\
4 & Impaired spontaneous ventilation \\
5 & Improved Respiratory Condition \\
6 & High Respiratory Rate \\
7 & Low Respiratory Rate \\
Cardiovascular System- Total of 6 NDs validated \\
1 & Presence of Hypertension \\
2 & Altered Blood Pressure \\
\hline & Peripheral Edema \\
\hline & Impaired Cardiovascular System \\
\hline
\end{tabular}

Renal and Digestive Systems - Total of 10 NDs validated

1 Impaired Urinary Condition

2 High Urinary Frequency

3 Impaired Intestinal Condition

4 Constipation

5 Intestinal Incontinence

6 Deglutition, Impaired

7 Urinary Incontinence

8 Impaired Gastrointestinal Condition

9 Risk of Constipation

10 Presence of Diabetes

Tegumental System- Total of 16 NDs validated

\begin{tabular}{lll}
1 & Impaired Skin Integrity & $100 \%$ \\
2 & Presence of Erythema & $100 \%$ \\
3 & Presence of Wound & $100 \%$ \\
\hline
\end{tabular}

$95.65 \%$

$95.65 \%$

$95.65 \%$

$95.65 \%$

$95.65 \%$

$91.3 \%$

$91.3 \%$

$91.3 \%$

$82.6 \%$

\begin{tabular}{|c|c|c|}
\hline \multicolumn{2}{|r|}{ Validated Nursing Diagnoses of the ICNP ${ }^{\circledR}$} & \multirow{2}{*}{$\begin{array}{c}\text { CVI\% } \\
100 \%\end{array}$} \\
\hline 4 & Presence of Bruise & \\
\hline 5 & Presence of Necrosis & $100 \%$ \\
\hline 6 & Arterial Ulcer & $100 \%$ \\
\hline 7 & Pressure Ulcer [Injury] & $100 \%$ \\
\hline 8 & Venous Ulcer & $100 \%$ \\
\hline 9 & Surgical Wound & $95.65 \%$ \\
\hline 10 & Impaired Standard Hygiene & $95.65 \%$ \\
\hline 11 & Presence of Pruritus & $95.65 \%$ \\
\hline 12 & "Delayed" Wound Healing & $91.3 \%$ \\
\hline 13 & Infection & $91.3 \%$ \\
\hline 14 & Presence of Foul Odor & $91.3 \%$ \\
\hline 15 & Allergy & $86.95 \%$ \\
\hline 16 & Inflammation & $86.95 \%$ \\
\hline \multicolumn{3}{|c|}{ Musculoskeletal System - Total of 8 NDs validated } \\
\hline 1 & Impaired Bed Mobility & $100 \%$ \\
\hline 2 & Paralysis & $100 \%$ \\
\hline 3 & Fall & $100 \%$ \\
\hline 4 & Risk of Fall & $100 \%$ \\
\hline 5 & Dependence to Stand & $95.65 \%$ \\
\hline 6 & Impaired Wheelchair Mobility & $91.3 \%$ \\
\hline 7 & Impaired Psychomotor Activity & $91.3 \%$ \\
\hline 8 & Impaired Walking Capacity & $91.3 \%$ \\
\hline \multicolumn{3}{|c|}{ Sociodemographic Aspects - Total of 19 NDs validated } \\
\hline 1 & Impaired Familiar Support & $100 \%$ \\
\hline 2 & Impaired Autonomy & $100 \%$ \\
\hline 3 & Caregiver Stress & $100 \%$ \\
\hline 4 & Caregiver Stress - Risk Potential & $100 \%$ \\
\hline 5 & Presence of Familiar Crisis & $100 \%$ \\
\hline 6 & Negligence Victim & $100 \%$ \\
\hline 7 & Negligence Victim - Risk Potential & $100 \%$ \\
\hline 8 & Conflictive Caregiver Attitude & $95.65 \%$ \\
\hline 9 & Deteriorated Self-Care & $95.65 \%$ \\
\hline 10 & Potential Social Isolation for Risk & $95.65 \%$ \\
\hline 11 & Potential for Autonomy & $95.65 \%$ \\
\hline 12 & Damaged Waste Collection Service (Trash and Sewer) & $95.65 \%$ \\
\hline 13 & Social Isolation & $91.3 \%$ \\
\hline 14 & Prescribed Polypharmaceuticals & $91.3 \%$ \\
\hline 15 & Low Family Income & $91.3 \%$ \\
\hline 16 & Impaired Water Treatment Service & $91.3 \%$ \\
\hline 17 & Family's Ability to Participate in Real Care Planning & $86.95 \%$ \\
\hline 18 & Caregiver's Ability to Perform Impaired Care & $86.95 \%$ \\
\hline 19 & Adherence to the Therapeutic Regime & $82.6 \%$ \\
\hline
\end{tabular}

To be continued
In Table 3, 28 (25.2\%) NDs having CVI lower than 80\% (0.8) are presented among the expert judges. CVIs of non-validated NDs ranged between $47.82 \%$ and $78.26 \%$, with an average CVI of $6.5 \%$, is considered satisfactory for home consultation performed by a nurse, however "no priority" by the expert judges. It calls the attention that the results obtained confirmed that no ND reached a minimum rate of $80 \%$ of the "not applicable" answer by the experts.

The data collection instrument allowed judges indicate new diagnoses for further validation, as specified: I) Reproductive System: risk of sexually transmitted infection, presence of climacteric, menopause and andropause; II) Respiratory System: 
changes in respiratory auscultation; III) Cardiovascular System: changes in cardiac auscultation and peripheral perfusion; IV) Neurologic System: inclusion of functional evaluation scales, NIHSS and Rankin, and pupil changes; V) Digestive and Renal Systems: risk of electrolyte disturbance. Judge also pointed out the need for the inclusion of Nursing Diagnoses related to adult immunization and conducting Rapid Diagnostic Tests, such as sexually transmitted diseases and pregnancy.

Table 3 - 2017 ICNP"s Nursing Diagnoses Statements non-validated and the Content Validity Index, Florianópolis, Santa Catarina, Brazil, 2019

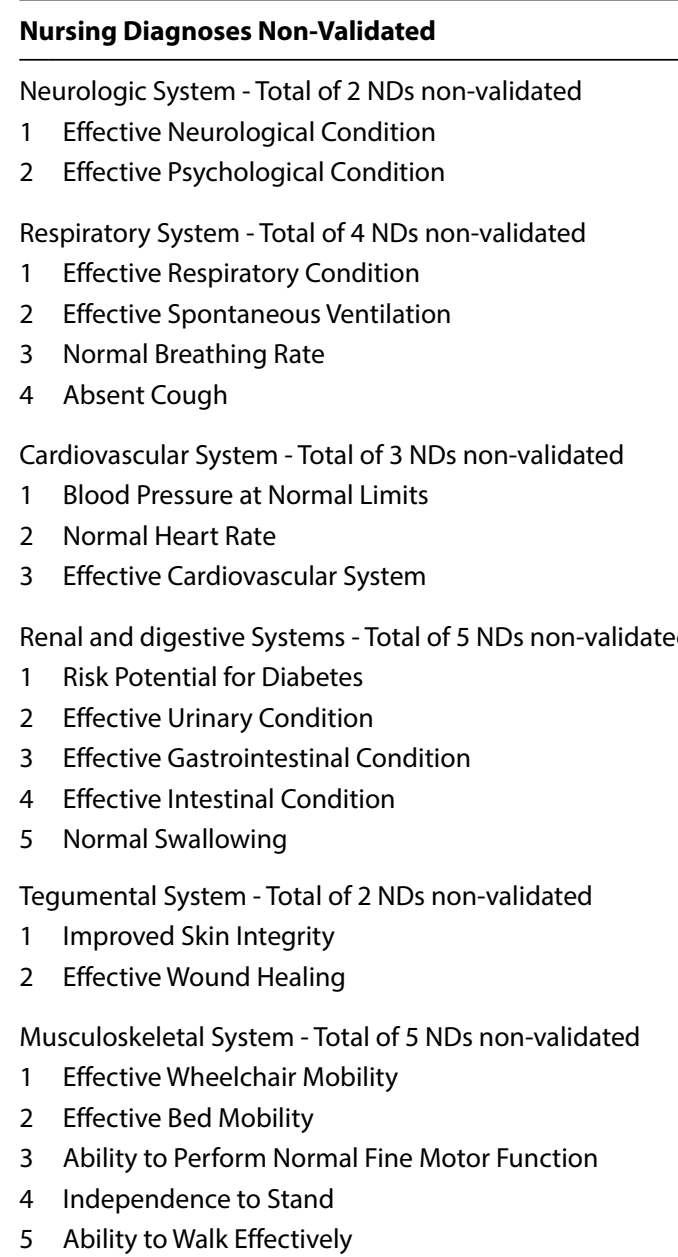

CVI\%

$69.56 \%$

$69.56 \%$

$69.56 \%$

$69.56 \%$

$60.86 \%$

$52.17 \%$

$60.86 \%$

$56.52 \%$

$56.52 \%$

$78.26 \%$

$60.86 \%$

$60.86 \%$

$60.86 \%$

$56.52 \%$

$73.93 \%$

$69.56 \%$

$73.93 \%$

$73.93 \%$

$65.21 \%$

$52.12 \%$

$47.82 \%$

Female and Male Reproductive System- Total of 1 ND non-validated

1 Risk of Impaired Reproductive Function

$47.82 \%$

Sociodemographic Aspects - Total of 6 NDs non-validated

1 Health Search Behavior

$78.26 \%$

2 Attitude towards Conflictive Care

$73.93 \%$

3 Damaged House Tidiness

4 Attitude towards Positive Care

5 Positive Family Support

6 Positive Caregiver Attitude

$69.56 \%$

$69.56 \%$

$65.21 \%$

$60.86 \%$

Note: ND - Nursing Diagnoses; CVI - Content Validity Index.

\section{DISCUSSION}

Home Care $(\mathrm{HC})$ has the potential to expand and qualify the care processes and enable the professionals to check the clients' needs and the respective possibilities of intervention, which differ according to local, sociodemographic, sanitary, and plurality of family dynamics ${ }^{(8,18-21)}$. Home care, while National public policy is wide, involves multiple health promotion, prevention, treatment, and rehabilitation actions, carried out by several health professionals ${ }^{(8)}$. In this context, the effective participation of nurses in home nursing consultations is confirmed, in addition to their many other attributions.

From the 19 Nursing Diagnoses that composed the neurologic system, 17 (89.5\%) were validated. The neurologic alterations affect cognitive, behavioral, and mobility aspects, and are usually observed in $\mathrm{HC}$ in any age groups. Nervous system injuries can be classified, among other types, as neurodegenerative or acquired. Neurodegenerative diseases are common to the elderly, such as Alzheimer's and Parkinson's disease, since the acquired injuries are related to infectious, traumatic, and vascular foci, as in the case of brain stroke, head trauma, and spinal cord trauma ${ }^{(22-25)}$.

Individuals with neurologic changes usually need home care and may have difficulties to ask for help. In this sense, non-verbal communication and the observation of changes in functionality are essentials in nursing care ${ }^{(8,21-22)}$. Such neurologic changes are aligned with NDs of the ICNP" validated by judges, including: "Impaired Neurologic Conditions", "Impaired Ability to Communicate Needs", "Signs of Discomfort", "Pain", "Agitation,, “Presence of Anguish", "Impaired Memory", "Impaired Ability to Participate in Care Planning".

Respiratory System had 7 (63.6\%) NDs validated. In home consultation, the nurse should evaluate the respiratory condition of the client. Changes in breathing patterns are frequent in home care and may be associated with other clinical changes. Among the main respiratory changes, there are cough, altered pulmonary auscultation, altered respiratory rate, oxygen saturation $\left(\mathrm{SatO}_{2}\right)$ below expectations ${ }^{(8,26)}$.

We can also find home clients with the use of tracheotomy, use of oxygen therapy, excess secretion in the airways, pneumonia, tuberculosis, and with a higher risk of bronchoaspiration and respiratory infections. Some clients are eligible for the home use of devices such as inhalers, respirators, oxygen therapy cylinders, or even non-invasive mechanical ventilation; and, in these situations, the presence of the nurse is essential. The nurse should follow up and continuously re-evaluate those clients to improve or readjust the therapeutic plan, in a way to guide and /or assist clients' and their families' demands $s^{(8,26-27)}$.

Regarding the cardiovascular system, expert judges validated 6 (66.6\%) diagnoses, including "Potential Risk for Hypertension", "Presence of Hypertension", "Altered Blood Pressure". Systemic Arterial Hypertension (SAH) affects $24.8 \%$ of Brazilians, being a serious public health problem and a risk factor for diseases such as cardiac ischemia, cerebrovascular, peripheral, and renal vascular disorders ${ }^{(28)}$. The nurse should instruct the client to prevent alterations and assist in blood pressure control, aiming to avoid complications ${ }^{(7,28-29)}$.

Renal and digestive systems had $10(66.6 \%)$ diagnoses validated. The ND "presence of diabetes" (CVI = 82.6\%) is relevant for nursing care, as it brings risks and complications to the client's health. It is estimated that, in Latin America, about $40 \%$ of people with diabetes do not know they have the disease, which increases the risk of complications and even death, especially when the correct treatment is not used ${ }^{(7,30-33)}$. 
The global prevalence of peripheral neuropathy related to decompensated and/or untreated diabetes is $66 \%$, and the presence of "diabetic foot" is prevailing in $6.4 \%$ of those clients. This is one of the complications resulting from diabetes, neuropathy triad, arteriopathy, and changes/loss of skin integrity. The changes resulting from such complications cause decreased sensitivity in the lower limbs and increase the risk of skin lesions, deficiency in the healing process, and an increase in the number of amputations up to twenty times in the population with diabetes compared to the general population ${ }^{(30-33)}$.

Early identification of the disease may provide a better quality of life to the individual; for that, there must be a multidisciplinary action aimed at investigating and confirming the diagnosis of diabetes. Data from 54 countries showed that $80 \%$ of the cases of severe renal disease are caused by diabetes and $44 \%$ of persons with diabetes developed some type of chronic renal disease. Also, the number of deaths in 2017 is extremely high $(209,717)$ among adults ranging from 20 to 79 years. This data represents $11 \%$ of all death cases in this age range, and it should be noted that half of these deaths were in $\mathrm{Brazi}^{(30,33)}$.

Also, regarding the digestive and renal systems in home care, occurrences of neurogenic bladder, enterovesical fistulas, kidney stones, bladder catheterization, or diaper use are common. In these cases, during home consultation, the nurse should pay attention to inform the guidelines for the client as well as the support network, such as instructing on hygiene care, probing techniques, and changing devices to prevent health problems, such as urinary infections ${ }^{(8)}$.

Other validated NDs "Constipation" (CVI = 95.65\%) and "Risk of Constipation" (CVl=91.3\%). Intestinal changes are frequent in home care, related to low fiber intake, low water intake, use of various medications, little or inadequate movement, and/or presence of injury. The Evolution of constipation leads to abdominal distention, poor food acceptance, gastroesophageal reflux, colic, and formation of fecaloma ${ }^{(8,34)}$. Thus, it is important to monitor stool eliminations and it should be observed/diagnosed by the nurse during the home visit.

Regarding the tegumental system, out of 18 NDs elaborated, $16(88.9 \%)$ were validated. Wounds and other soft tissue affections are the most frequent health conditions seen in the context of Home Care. Studies show that, in home consultations, some risk factors should be monitored for skin lesions, such as poor tissue perfusion, anemia, malnutrition, hypoxia, diabetes, changes in mobility and changes in the client's level of consciousness, as well as existing surgical/postoperative wounds ${ }^{(8,23,35-37)}$.

Concerning wounds, pressure injuries (LPP) resulting from skin compression, shear, friction, or even the combination of these factors, mainly in bony prominences, cause damage to the underlying skin tissue and are present among the main changes in the tegumental system of clients that receive care at home. LPPs are, up to $95 \%$ of the time, avoidable, and its prevention is considered a goal for patient safety. Studies point out that the risk to develop LPP at home is up to $59 \%$, with a prevalence of up to $23 \%{ }^{(35-37)}$.

It is worth to mention that nurses are aware of this area and should contribute to the prevention of skin changes, evaluate development risks, evaluate existing injuries and their prognosis since its occurrence causes a huge impact to the clients and their families, as well as they extend the time of treatment, increase the risk of infection, and cause pain to the person ${ }^{(36,38-39)}$.

The musculoskeletal system had 8 (61.5\%) NDs validated. The changes in this system are among the more disabling causes of the geriatric population, leading to mobility difficulties that can restrict their Basic Activities of Daily Living, favor falls, social isolation, and even depression ${ }^{(8,40-41)}$. NDs validated in this study include the possible mentioned changes, such as: "Risk of Fall", "Fall", "Impaired Ability to Walk", "Impaired Psychomotor Activity", and "Dependence to Stand".

The difficulty in moving is still an obstacle for the client to seek health assistance, which enables consultation with nurses at home essential for health promotion and prevention. The professional may help in the environment adaptations and/or provide devices that assist the pace and promote the autonomy to perform Instrumental Activities of Daily Living (IADLs) ${ }^{(42-43)}$. In these situations, there is still a strong association with bed restriction, increasing the risk of respiratory and digestive problems. It is worth mentioning that, in such cases, multidisciplinary work is essential to provide suitable support to ensure the improvement of the quality of life of these clients ${ }^{(8,40-43)}$.

Regarding the list of NDs elaborated for validation, in the group "Sociodemographic Aspects", judges validated 19 out of 25 NDs. It is noticed that these aspects may be evaluated and diagnosed by nurses during the home nursing consultation, since they refer to the real life of the clients, their relatives, and home conditions, as well as provide aids for intervention according to the clinical conditions of the client.

Regarding the 28 (25.2\%) non-validated NDs (CVI $\leq 0.8)$, it was concluded that they obtained CVI satisfactory, however, not a priority, according to the expert judges. It is noteworthy that the majority of Nursing Diagnoses non-validated by judges are related to health situations/conditions considered as "effective" or "improved" by clients. Besides, it is also noteworthy that the ICNP", for the composition of NDs, considers such terms from the "judging axis", and these still can be considered as nursing practice results ${ }^{(9)}$.

\section{Study limitations}

Limitations mean the difficulties to receiving the forms submitted to nurses through email, as well as the low number of specialist nurses in the use of the ICNP ${ }^{\circ}$ while a reference terminology - considering the recent and not widespread use in Brazil, despite it is evident the growing number of surveys with interest in the use of a standard nursing language.

\section{Contributions to the field}

Nursing Diagnoses (ND) of the ICNP validated in this study may be used to assist clients and their families in nursing home consultations in Primary Health Care. Thus, as a contribution to the practice, the use of diagnoses obtained as a priority may help nurses in the organization of data, planning, clinical reasoning, and also in the professional-client relationship.

It is still recommended that other validation studies of nursing diagnoses are carried out to create a list of priority diagnoses facilitating the routine of the practitioners and contributing to the development of clinical reasoning of the nurses. 


\section{CONCLUSIONS}

According to the expert judges, the study identified the priority of Nursing Diagnostics of the ICNP ${ }^{\circ}$ for the adult home nursing consultation in Primary Health Care. They confirmed as "priority" or "very priority" 83 (74.8\%) of the 111 statements of Nursing Diagnoses elaborated, which contemplated all human systems and the sociodemographic aspects of the clients.

\section{REFERENCES}

1. Conselho Federal de Enfermagem-COFEN. Resolução COFEN n 358/2009. Sistematização da Assistência de Enfermagem e a implementação do Processo de Enfermagem em ambientes, públicos ou privados, em que ocorre o cuidado profissional de Enfermagem, e dá outras providências. [Internet]. Brasília, DF, 2009[cited 2019 Feb 15]. Available from: http://www.cofen.gov.br/resoluocofen-3582009_4384.html

2. Conselho Federal de Enfermagem-COFEN. Resolução Cofen n 0464/2014. Normatiza a Atuação da Equipe de Enfermagem na Atenção Domiciliar. [Internet]. Brasília, DF, 2014[cited 2019 Feb 15]. Available from: http://www.cofen.gov.br/resolucao-cofen-no-04642014_27457.html

3. Moreira MDS, Gaiva MAM. Approach of the child's life context of the in the nursing appointment. Rev Pesqui: Cuid Fundam. 2017;9(2):43240. https://doi.org/10.9789/2175-5361.2017.v9i2.432-440

4. Ministério da Saúde (BR). Portaria n॰ 825, de 25 de Abril de 2016. Redefine a Atenção Domiciliar no âmbito do Sistema Único de Saúde (SUS) e atualiza as equipes habilitadas. [Internet]. Brasília, DF, 2016[cited 2019 Feb 15]. Available from: http://bvsms.saude.gov.br/bvs/saudelegis/ gm/2016/prt0825_25_04_2016.html

5. Joaquim FL, Camacho ACLF, Silva RMCRA, Leite BS, Queiroz RS, Assis CRC. Impact of home visits on the functional capacity of patients with venous ulcers. Rev Bras Enferm. 2017;70(2):287-93. https://doi.org/10.1590/0034-7167-2016-0291

6. Ferreira SRS, Périco LAD, Dias VRFG. The complexity of the work of nurses in Primary Health Care. Rev Bras Enferm. 2018;71(Suppl 1):704-9. https://doi.org/10.1590/0034-7167-2017-0471

7. Moraes, JT, Fonseca DF, Mata LRF, Oliveira PP, Sampaio FC, Silva JF. Validação de um instrumento para consulta de enfermagem à pessoa com diabetes mellitus e/ou hipertensão arterial. Rev Enferm Ref. 2018;serIV(19):127-35. https://doi.org/http://dx.doi.org/10.12707/RIV18041

8. Ministério da Saúde (BR). Secretaria de Atenção à Saúde. Departamento de Atenção Básica. Caderno de Atenção Domiciliar [Internet]. Brasília, DF: Ministério da Saúde, 2013[cited 2019 Feb 15]. v.2: il. Available from: http://bvsms.saude.gov.br/bvs/publicacoes/caderno_ atencao_domiciliar_melhor_casa.pdf

9. Conselho Internacional de Enfermeiros (CIE). Classificação Internacional para a Prática de Enfermagem - CIPE ${ }^{\circledR}$. Versão 2017. São Paulo: Algol; 2017.

10. Marin HF, Peres HHC, Dal Sasso GTM. Categorical structure analysis of ISO 18104 standard in nursing documentation. Acta Paul Enferm. 2013;26(3):299-306. https://doi.org/10.1590/S0103-21002013000300016

11. International Organization for Standardization (ISO). ISO 18.104: 2014[Internet]. Geneva, Switzerland, 2014 Classificação Internacional para a Prática de Enfermagem - CIPE ${ }^{\oplus}$. Available from: https://www.iso.org/standard/59431.html Acesso em: 17 de fevereiro de 2019.

12. Clares JWB, Nóbrega MML, Guedes MVC, Silva LF, Freitas MC. ICNP ${ }^{\circledR}$ nursing diagnoses, outcomes and interventions for community elderly. Rev Bras Enferm. 2019;72(Suppl 2):191-8. doi:10.1590/0034-7167-2018-0540

13. Beserra PJF, Gomes GLL, Santos MCF, Bittencourt GKGD, Nóbrega MML. Scientific production of the International Classification for Nursing Practice: a bibliometric study. Rev Bras Enferm. 2018;71(6):2860-8. https://doi.org/10.1590/0034-7167-2017-0411

14. Phillips AC, Lewis LK, McEvoy MP, Galipeau J, Glasziou P, Moher D, et al. Development and validation of the guideline for reporting evidencebased practice educational interventions and teaching (GREET). BMC Med Educ. 2016;16(1):237. https://doi.org/10.1186/s12909-016-0759-1

15. Polit DF, Beck CT. Fundamentos de pesquisa em enfermagem: avaliação de evidências para a prática da enfermagem. Porto Alegre: Artmed; 2018. 456p.

16. Fehring RJ. Methods to validate nursing diagnoses. Heart Lung [Internet]. 1987 [cited 2020 Feb 19];16(6):625-9. Available from: https://pdfs. semanticscholar.org/11f7/d8b02e02681433695c9e1724bd66c4d98636.pdf

17. Coluci MZO, Alexandre NMC, Milani D. Construção de instrumentos de medida na área da saúde. Cienc Saude Colet. 2015;20(3):925-36. https://doi.org/10.1590/1413-81232015203.04332013

18. Sena RR. Atenção domiciliar: oportunidades e desafio para a enfermagem. Rev Min Enferm. 2014;18(2):268-71. https://doi. org/10.5935/1415-2762.20140020

19. Procópio LCR, Seixas CT, Avellar RS, Silva KL, Santos MLM. Home care within the Unified Health System: challenges and potentialities. Saúde Debate. 2019;43(121):592-604. https://doi.org/10.1590/0103-1104201912123

20. Lopes GVDO, Vilasbôas ALQ, Castellanos MEP. Home care in the family health strategy: implementation degree analysis in the city of Camaçari (BA). Saúde Debate. 2017;41(esp 3):241-54. https://doi.org/10.1590/0103-11042017s318

21. Andrade AM, Castro EAB, Brito MJM, Braga PP, Silva KL. Nursing practice in home care: the mediation of care by reflexivity. Rev Bras Enferm. 2019;72(4):956-63. https://doi.org/10.1590/0034-7167-2018-0431 
22. Carnaúba CMD, Silva TDA, Viana JF, Alves JBN, Andrade NL, Trindade Filho EM. Clinical and epidemiological characterization of patients receiving home care in the city of Maceió, in the state of Alagoas, Brazil. Rev Bras Geriatr Gerontol. 2017;20(3):352-62. https://doi. org/10.1590/1981-22562017020.160163

23. Rodrigues RAP, Bueno AA, Casemiro FG, Cunha AN, Carvalho LPN, Almeida VC, et al. Assumptions of good practices in home care for the elderly: a systematic review. Rev Bras Enferm. 2019;72(Suppl2):302-10. https://doi.org/10.1590/0034-7167-2018-0445

24. Xavier GTO, Nascimento VB, Carneiro Jr N. The contribution of Home Care to the construction of health care networks from the perspective of health professionals and elderly users. Rev Bras Geriatr Gerontol. 2019;22(2):e180151. https://doi.org/10.1590/1981-22562019022.180151

25. Muniz EA, Freitas CASL, Oliveira EM, Lacerda MR. Atenção domiciliar ao idoso na Estratégia Saúde da Família: perspectivas sobre a organização do cuidado. Rev Enferm UFPE. 2017;11(Supl. 1):296-302. https://doi.org/10.5205/reuol.7995-69931-4-SM.1101sup201707

26. Vidotto LS, Carvalho CRF, Harvey A, Jones M. Disfunção respiratória: o que sabemos? J Bras Pneumol. 2019;45(1):e20170347. https://doi. org/10.1590/1806-3713/e20170347

27. Fernandes CA, Gomes JA, Magalhães BM, Lima AMN. Knowledge production in Portuguese rehabilitation nursing: scoping review. J Health NPEPS. 2019;4(1):282-301. https://doi.org/10.30681/252610103378

28. Ministério da Saúde (BR). Hipertensão é diagnosticada em 24,7\% da população, segundo a pesquisa Vigitel[Internet]. Brasília, DF, 2019[cited 2020 Apr 19]. Available from: http://www.saude.gov.br/noticias/agencia-saude/45446-no-brasil-388-pessoas-morrem-por-diapor-hipertensao

29. Silveira A, Favero N, Silva J, Rodrigues D, Caurio AP. Pacientes em condições crônicas de saúde: cotidiano de cuidado domiciliar. RCS. 2019;19(36):39-5. https://doi.org/https://doi.org/10.21527/2176-7114.2019.36.39-45

30. Sociedade Brasileira de Diabetes. Atlas IDF 2017: Diabetes no Brasil[Internet]. São Paulo, SP. 2017[cited 2020 Apr 19]. Available from: https:// www.diabetes.org.br/profissionais/images/pdf/atlas_sbd_novo.pdf

31. Teston EF, Arruda GO, Sales CA, Serafim D, Marcon SS. Nursing appointment and cardiometabolic control of diabetics: a randomized clinical trial. Rev Bras Enferm. 2017;70(3):468-74. https://doi.org/10.1590/0034-7167-2016-0352

32. Silva CS, Tomaz AF, Nascimento WGN, Silva APT, Alves JP. Caracterização da consulta de enfermagem na atenção à pessoa com hipertensão e diabetes. Rev Port: Saúde Soc. 2017;2(1):347-62. https://doi.org//10.28998/rpss.v2i1.3264

33. Silveira A, Favero N, Silva J, Rodrigues D, Caurio AP. Pacientes em condições crônicas de saúde: cotidiano de cuidado domiciliar. RCS. 2019;19(36):39-5. https://doi.org/10.21527/2176-7114.2019.36.39-45

34. Campoy LT, Rabeh SAN, Castro FFS, Nogueira PC, Terçariol CAS. Bowel rehabilitation of individuals with spinal cord injury: video production. Rev Bras Enferm. 2018;71(5):2376-82. https://doi.org/10.1590/0034-7167-2017-0283

35. Machado DO, Mahmud SJ, Coelho RP, Cecconi CO, Jardim GJ, Paskulin LMG. Pressure injury healing in patients followed up by a home care service. Texto Contexto Enferm. 2018;27(2):e5180016. https://doi.org/10.1590/0104-07072018005180016

36. Almeida F, Costa MMS, Ribeiro EES, Santos DCO, Silva NDA, Silva RE, et al. Assistência de enfermagem na prevenção da lesão por pressão: uma revisão integrativa. Rev Eletrôn Acervo Saúde. 2019;30,e1440. https://doi.org/10.25248/reas.e1440.2019

37. Diniz EM, Morita ABPS, Paula MAB. Situação de risco para úlceras por pressão em uma unidade de assistência domiciliar. Estima. 2016;14(2):53-60. https://doi.org/10.5327/Z1806-3144201600020002

38. Soares $\mathrm{CF}$, Heidemann ITSB. Health promotion and prevention of pressure injury: expectations of primary health care nurses. Texto Contexto Enferm. 2018;27(2):1-9. https://doi.org/10.1590/0104-070720180001630016

39. Meireles VC, Baldissera VDA. Quality of care for the elderly: pressure injury risk as a marking condition. Rev Rene. 2019;20:e40122. https:// doi.org/10.15253/2175-6783.20192040122

40. Rocha VM, Gaspar HA, Oliveira CF. Estimativa do risco de fratura óssea em pacientes em Atenção Domiciliar por meio da ferramenta FRAX Einstein. 2018;16(3):eAO4236. https://doi.org/10.1590/S1679-45082018AO4236

41. Martins DMC, Castro JGD. Idosos dependentes de cuidados domiciliares: revisão de literatura. Rev Desafios. 2018;5(2):91-102. https://doi. org/10.20873/uft.2359-3652.2018vol5n2p91

42. Santos GLA, Santana RF, Broca PV. Capacidade de execução das atividades instrumentais de vida diária em idosos: Etnoenfermagem. Esc Anna Nery. 2016;20(3):e20160064. https://doi.org/10.5935/1414-8145.20160064

43. Farías-Antúnez S, Lima NP, Bierhals IO, Gomes AP, Vieira LS, Tomasi E. Disability related to basic and instrumental activities of daily living: a population-based study with elderly in Pelotas, Rio Grande do Sul, 2014. Epidemiol Serv Saúde. 2018;27(2):e2017290. https://doi. org/10.5123/s1679-49742018000200005 